\title{
Deodorized Tincture of Opium
}

National Cancer Institute

\section{Source}

National Cancer Institute. Deodorized Tincture of Opium. NCI Thesaurus. Code C28968.

An opium tincture with antidiarrheal activity. The opiate morphine, in deodorized tincture of opium, increases the tone of the smooth muscle in the intestines. It stops the normal movement and slows down the passage of intestinal contents. This allows water to be absorbed from the liquid stool thereby decreasing diarrhea. 